Reprod. Nutr. Dévelop., 1985, 25 (2), 355-366.

\title{
Changes in testicular fluid production and plasma hormones in the adult rat after testicular ${ }^{60} \mathrm{Co}$ irradiation
}

\author{
P. LAPORTE $\left({ }^{1}, 2\right)$, Marie-Claude VIGUIER-MARTINEZ $\left({ }^{1}, 2\right)$, D. ZONGO $\left(^{2}\right)$, \\ O. LE FLOCH (3), F. LIPINSKI (3)
}

(1) Station de Physiologie de la Reproduction, I.N.R.A., Nouzilly, 37380 Monnaie, France.

(2) Laboratoire Physiologie Comparée, Faculté des Sciences, 37200 Tours.

(3) C.H.U. "Bretonneau ", Service de Radiothérapie, 37044 Tours Cedex.

\begin{abstract}
Summary. Adult Wistar rats exposed to testicular radiocobalt irradiation $(0.8 \mathrm{~Gy})$ were alloted to four groups : sham control, protected control, unilaterally irradiated and bilaterally irradiated. The rats of each group were killed $30,45,60,75$ and 105 days after $\gamma$ ray exposure and/or general anaesthesia. Tubular fluid (TF) production, estimated by ligature of the efferent ducts of both unilaterally and bilaterally irradiated testes, $24 \mathrm{~h}$ prior to sacrifice, was transiently increased 30 and 45 days after irradiation $(\mathbb{P}<0.001)$; there was no increment in the interstitial fluid (or lymph) collected compared to sham and protected control testes. At $\mathbf{3 0}$ and $\mathbf{4 5}$ days, irradiated testis weight decreased significantly. From 60 to 105 days after $\gamma$-ray exposure, TF gradually returned to control levels, while the testicular weight increased. The plasma FSH, LH, PRL and testosterone of the irradiated rats did not change significantly compared to the controls. Consequently, it is presumed that TF secretion was regulated locally by a germ cell-Sertoli cell interrelationship.
\end{abstract}

\section{Introduction.}

Testicular fluid (TF) enters the efferent ducts of the testis. Recent observations suggest that it originates in the seminiferous tubules, even though its composition in the rete testis may be modified (Setchell, 1978 ; Free, 1980). The continued production of TF in the almost complete absence of germ cells, following prenatal busulfan treatment, suggests that the Sertoli cells are responsible for its production (Setchell, 1969 ; Laporte, 1979 ; Laporte and Gillet, 1984). The hormonal regulation of TF is poorly understood (Waites, 1977 ; Ritzen et al., 1981 ; Waites and Gladwell, 1982), and it has been proposed that TF flow is not directly controlled by hormones (Setchell, 1978). We have previously described an inverse relationship between TF production and the presence of germ cells in busulfan-treated adult rats (Laporte and Gillet, 1975). This interrelationship may be influenced by peripheral and/or local factors. In an attempt to define the origin of these factors, we compared the effects of unilateral and bilateral testicular irradiation in rats. The latter process allowed us to mimic the effects of busulfan treatment without separating the central and/or 
local regulatory factors. Conversely, in unilaterally irradiated rats, significant differences between the fluid productions of a normal and an irradiated testis in the same animal would indicate preponderant local control of TF secretion. A possible interference with the testicular lymph or interstitial fluid (IF) was also investigated.

\section{Material and methods.}

Experiment 1. Tubular fluid production and plasma hormone levels after local irradiation.

Animals. - Adult male Wistar rats 4 months old and having a mean body weight of $432 \pm 8 \mathrm{~g}$ were housed in groups in cages under controlled light (14L : 10D) and temperature $\left(22^{\circ} \mathrm{C}\right)$; a special UAR diet and tap water were given ad libitum.

Irradiation and surgical procedures. - The rats were slightly anaesthetized with sodium pentobarbitone (Nembutal Abbott; $25 \mathrm{mg} / \mathrm{kg}$ body weight i.p.) and placed on a plastic support in a prone position. Shielding the rest of the body, we exposed the scrotal area to irradiation by a medical $\gamma$-ray machine (Cobalt 60 source ; skin source distance : $70 \mathrm{~cm}$ ). The gonads were subjected to a total dose of $0.8 \mathrm{~Gy}$ in one dose over a period of nearly $1 \mathrm{~min}$. When the rats were irradiated unilaterally (right testis), the contralateral testis was protected against the $\gamma$-rays by pushing it back into the abdomen through the inguinal canal and placing a 5$\mathrm{cm}$ lead block over it. The control rats were only anaesthetized.

Twenty-four hours before sacrifice, all the rats were anaesthetized with ether for $10 \mathrm{~min}$, during which time the efferent ducts of one testis were ligated and the other testis was removed and weighed immediately. At 30, 45, 60, 75 and 105 days following irradiation (nembutal anaesthesia for the sham controls), 5 or more rats of each group were decapitated. The blood samples of all the rats were collected from the neck and centrifuged ; the plasma was frozen until assayed for testosterone, PRL and gonadotropins. The seminal vesicles and ligated testes were promptly dissected out and weighed.

Estimate of tubular fluid. - 126 rats were randomly allocated to four groups and treated (table 1). Both testes of each sham control and bilaterally irradiated rat were treated similarly so that their fluid production could be determined simply by the difference between the water content of the ligated right testis and that of the contralateral unligated testis (Smith, 1962). Since such a comparison was not possible in unilaterally irradiated rats, they were subdivided into two groups. In the first group (table 1), the irradiated testis of each rat was ligated but not the intact contralateral testis. The reverse was performed in the second group. TF production in these rats could be determined only by the difference between the water content of the ligated testis (irradiated or protected) of one animal and the water content of the unligated testis (irradiated or protected) of another.

To avoid any subjectivity in choosing the corresponding testes (ligated or not) of different rats in the unilaterally irradiated and protected control groups, to 
TABLE 1

Details on experimental groups of rats used for testicular fluid (TF) determination after local irradiation and or general anaesthesia.

\begin{tabular}{|c|c|c|c|c|c|}
\hline \multicolumn{4}{|c|}{ Experimental design } & \multicolumn{2}{|c|}{ TF Determination } \\
\hline \multirow{2}{*}{ Treatment } & \multirow{2}{*}{$\begin{array}{l}\text { No. of } \\
\text { rats }\end{array}$} & \multicolumn{2}{|c|}{ Status of testes } & \multirow{2}{*}{ Group } & \multirow{2}{*}{ Status of testes } \\
\hline & & Right & Left & & \\
\hline $\begin{array}{l}\text { No irradiation } \\
\text { Unilateral irradiation } \\
\text { Unilateral irradiation } \\
\text { Bilateral irradiation }\end{array}$ & $\begin{array}{l}32 \\
31 \\
33 \\
30\end{array}$ & $\begin{array}{l}\mathrm{N}-\mathrm{li} \\
(\bullet)^{-} \mathrm{I} \\
(\bullet)^{-} \mathrm{I}-\mathrm{li} \\
\mathrm{I}-\mathrm{li}\end{array}$ & $\begin{array}{c}N \\
(\bullet \bullet)^{N} N-l i \\
(\bullet \bullet) N \\
I\end{array}$ & $\begin{array}{l}\text { Sham control } \\
\text { Protected control } \\
\text { Unilaterally irradiated } \\
\text { Bilaterally irradiated }\end{array}$ & $\begin{array}{c}\mathrm{N}-\mathrm{li} \text { and } \mathrm{N} \\
(\bullet \bullet) \mathrm{N}-\mathrm{li} \text { and }(\bullet \bullet) \mathrm{N} \\
(\bullet) \mathrm{I} \text {-li and }(\bullet)) \\
\mathrm{I}-\mathrm{li} \text { and I }\end{array}$ \\
\hline
\end{tabular}

$\mathrm{I}, \mathrm{N}$ and li signify respectively : irradiated, normal and ligated testis.

$(\bullet)$ and $(\bullet \bullet)$ : Groups with testes from different rats for TF determination.

make each ligated testis its own control, and to improve between-group comparisons by applying the same method of TF determination in each group, we used the following procedures in all groups:

- true water content, determined by the difference between the wet weight of the testis and the sum of the dry weights after 48-hour lyophilization of the tunica albuginea and the testicular parenchyma ;

- true water concentration, expressed in $\mathrm{mg}$ of true water content per mg of dry testicular parenchyma ;

- supposed water content, a product of the mean value of the true water concentration of unligated testes (of the same rats in the sham control and bilaterally irradiated group but of different rats in the unilaterally irradiated and protected control groups) and the dry weight of the parenchyma of each ligated testis.

Finally, fluid production was determined by the difference between true water content after 24-hour efferent duct ligation and the supposed water content of the same testis before ligation.

Hormone assay. - Plasma samples were analysed for FSH content using a specific radioimmunoassay kit for rat FSH (NIAMDD) and for LH content using a specific double antibody radio-immunoassay (Viguier-Martinez, 1976). The results were expressed in terms of NIAMDD rat FSH-RP 1 for FSH and rat LH S $\times 1-1$ for LH. One unit of LH S $\times 1$ 1-1 was equivalent to 1.58 unit of NIH-LH S $\times 1-1$. The detection limit was $100 \mathrm{ng} / \mathrm{ml}$ for $\mathrm{FSH}$ and $0.6 \mathrm{ng} / \mathrm{ml}$ for $\mathrm{LH}$; the intra-assay coefficient of variation was $10 \%$ for LH and FSH. Plasma levels of PRL were measured using a specific radioimmunoassay method (Martinat et al., 1979). The potency of the standard (PRL-INRA) was about twice that of the NIAMDD rat PRL RP 1. The detection limit was $0.3 \mathrm{ng} / \mathrm{ml}$ and the intra-assay coefficient of variation was $10 \%$. Plasma testosterone was measured after solvent extraction ( $2 \mathrm{ml}$ of ethyl-acetate/cyclohexane mixture, $1 \mathrm{~V} / 1 \mathrm{~V}$, per $0.3 \mathrm{ml}$ plasma) using a RIA method (Viguier-Martinez et al., 1984). The detection limit was $50 \mathrm{pg} / \mathrm{ml}$ and 
the intra-assay coefficient of variation was $6 \%$. All samples of each hormone were processed in duplicate. The hormone concentrations were determined using logit-log transformation.

\section{Experiment 2. Interstitial and tubular fluid productions after local irradiation.}

We carried out a second experiment to determine whether $\gamma$-ray exposure modified the production of interstitial fluid (IF). Thirty-three Wistar rats were alloted to three groups (non-irradiated, unilaterally irradiated and bilaterally irradiated) and sacrificed 30 and 45 days after treatment. IF production was measured by the method of Sharpe (1977). Briefly, a small incision was made in the caudal end of the unligated testis, taking care to cut only the tunica albuginea and not the underlying seminiferous tubules. The testis was then immediately placed upright in a preweighed glass tube so that the testis was suspended 1 to $2 \mathrm{~cm}$ above the bottom of the tube. IF was allowed to collect for $24 \mathrm{~h}$ at $4{ }^{\circ} \mathrm{C}$. The tubes were covered with parafilm to avoid evaporation. Subsequently, the testes were removed from the tubes and the tubes were weighed. The recovered fluid was equated with IF production. Finally, the dry weights of the unligated and ligated testes were determined to estimate TF production, as in experiment 1 , but in the sham control and bilaterally irradiated groups only.

Statistical analysis. - Data from both experiments were expressed as the mean \pm SEM. The significance of the differences between the cotrol and irradiated groups at different times was assessed by Student's t-test.

\section{Results.}

\section{Experiment 1.}

Effects of $\gamma$-ray exposure on body and testicular weights. - In all the groups of rats body weight increased regularly with age. The mean body weight of rats killed 30 and 105 days after treatment was $454 \pm 6 \mathrm{~g}$ and $505 \pm 11 \mathrm{~g}$, respectively. There were no significant differences in body weight among groups of the same age. At no time after treatment was there any difference between the wet weights of sham and protected control testes (fig. 1). However, 30 and 45 days after irradiation there was a statistically significant decrease $(P<0.01)$ in the mean testicular wet weight of unilaterally and bilaterally irradiated rats compared to both control testes (fig. 1). Later, the weight of the irradiated testes of both groups increased regularly and did not differ from that of the control testes 60, 75 and 105 days after irradiation. There was no difference in any group as to the mean dry weight of ligated and unligated testes of the same rats (sham control and bilaterally irradiated) or of different animals (protected control and unilaterally irradiated) 30 and 45 days after irradiation or sham exposure (fig. 1).

However, the dry weight of all the irradiated testes (ligated or not) was significantly lower $(P<0.01)$ than that of either type of control testes 30 and 45 days after treatment.

At no time after treatment were there any significant differences among the groups of rats as to mean seminal vesicle weight. 

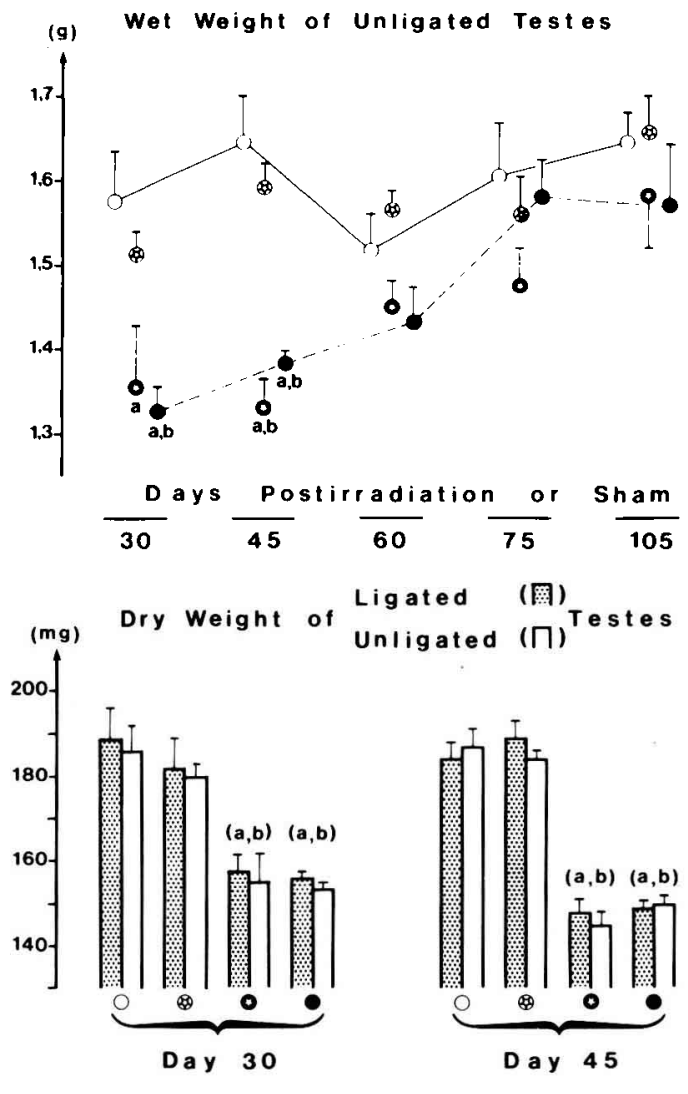

Postirradiation or Sham

FIG. 1. - Changes in wet and dry testicular weights ( $m \pm$ SEM) of rats 30 to 105 davs after bilateral (O) or unilateral $(0)$ testicular irradiation. Significant differences $(P<0.01)$ between means for irradiated testes and those of sham $1 \mathrm{O})$ and protected (Bib) control testes are indicated by superscripts $a$ and $b$, respectively.

TABLE 2

Daily production of tubular fluid (mg) by normal (sham and protected controls) and irradiated (unilaterally and bilaterally) rat testes.

\begin{tabular}{|c|c|c|c|c|}
\hline $\begin{array}{l}\text { Post-irradiation } \\
\text { days }\end{array}$ & Sham control & $\begin{array}{l}\text { Protected } \\
\text { control }\end{array}$ & $\begin{array}{l}\text { Unilaterally } \\
\text { irradiated }\end{array}$ & $\begin{array}{l}\text { Bilaterally } \\
\text { irradiated }\end{array}$ \\
\hline 30 & $428 \underset{(5)}{ \pm} 14$ & $493 \underset{(5)}{ \pm} 29$ & $\begin{array}{l}556 \pm 11 \\
\text { (a) (6) }\end{array}$ & $\begin{array}{l}549 \pm 11 \\
\text { (a) (5) }\end{array}$ \\
\hline 45 & $418 \underset{(8)}{ \pm} 14$ & $421 \underset{(8)}{ \pm} 14$ & $\begin{array}{l}522 \pm 27 \\
\text { (a) (8) (b) }\end{array}$ & $\begin{array}{l}568 \pm 19 \\
\text { (a) (7) (b) }\end{array}$ \\
\hline 60 & $412 \underset{(6)}{ \pm} 12$ & $456 \underset{(7)}{ \pm} 15$ & $464 \underset{(6)}{ \pm} 21$ & $\begin{array}{l}470 \pm 22 \\
\text { (a) (7) }\end{array}$ \\
\hline 75 & $451 \underset{(5)}{ \pm} 25$ & $417 \underset{(5)}{ \pm} 16$ & $435 \pm 7$ & $421 \underset{(6)}{ \pm} 18$ \\
\hline 105 & $425 \underset{(8)}{ \pm} 17$ & $410 \underset{(6)}{ \pm} 14$ & $431 \underset{(6)}{ \pm} 21$ & $412 \pm 7$ \\
\hline
\end{tabular}

(a) $(P<0.01)$; (b) $(P<0.001)$ : significant differences between means of irradiated testes and sham (a) or protected (b) control testes.

Mean $( \pm S E M) ;($ ) No. of rats.

Reproduction Nutrition Développement, $n^{\circ} 2-85 .-2$. 
Tubular fluid production. - The accumulation of fluid after 24-hour ligation of the testes increased significantly 30 and 45 days after irradiation in both unilaterally and bilaterally irradiated testes (table 2) compared with sham control testes, and at day 45 compared with both sham and protected control testes. Thereafter, the difference in TF production between irradiated and control rats decreased progressively and disappeared at 75 and 105 days post-irradiation.

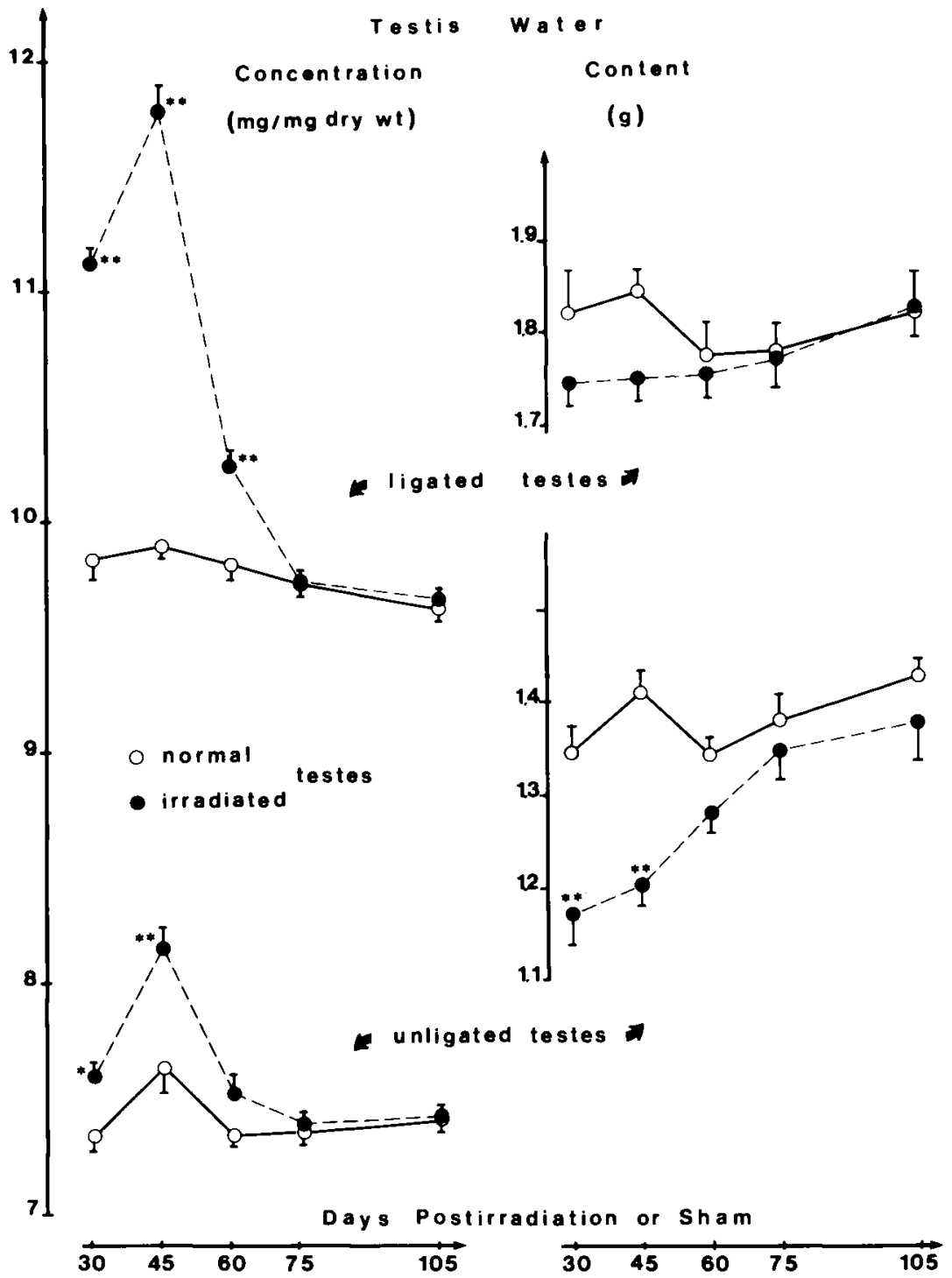

FIG 2. - Changes in absolute and relative water content in ligated and unligated testes of rats, 30 to 105 days after testicular irradiation or sham operation. Both values of bilaterally and unilaterally irradiated gonads $(O)$ are associated as for sham and protected control ones $(\mathrm{O})$. The significance of differences between the two groups is indicated as follows: ${ }^{*} P<0.01$ and ** $P<0.001$. 

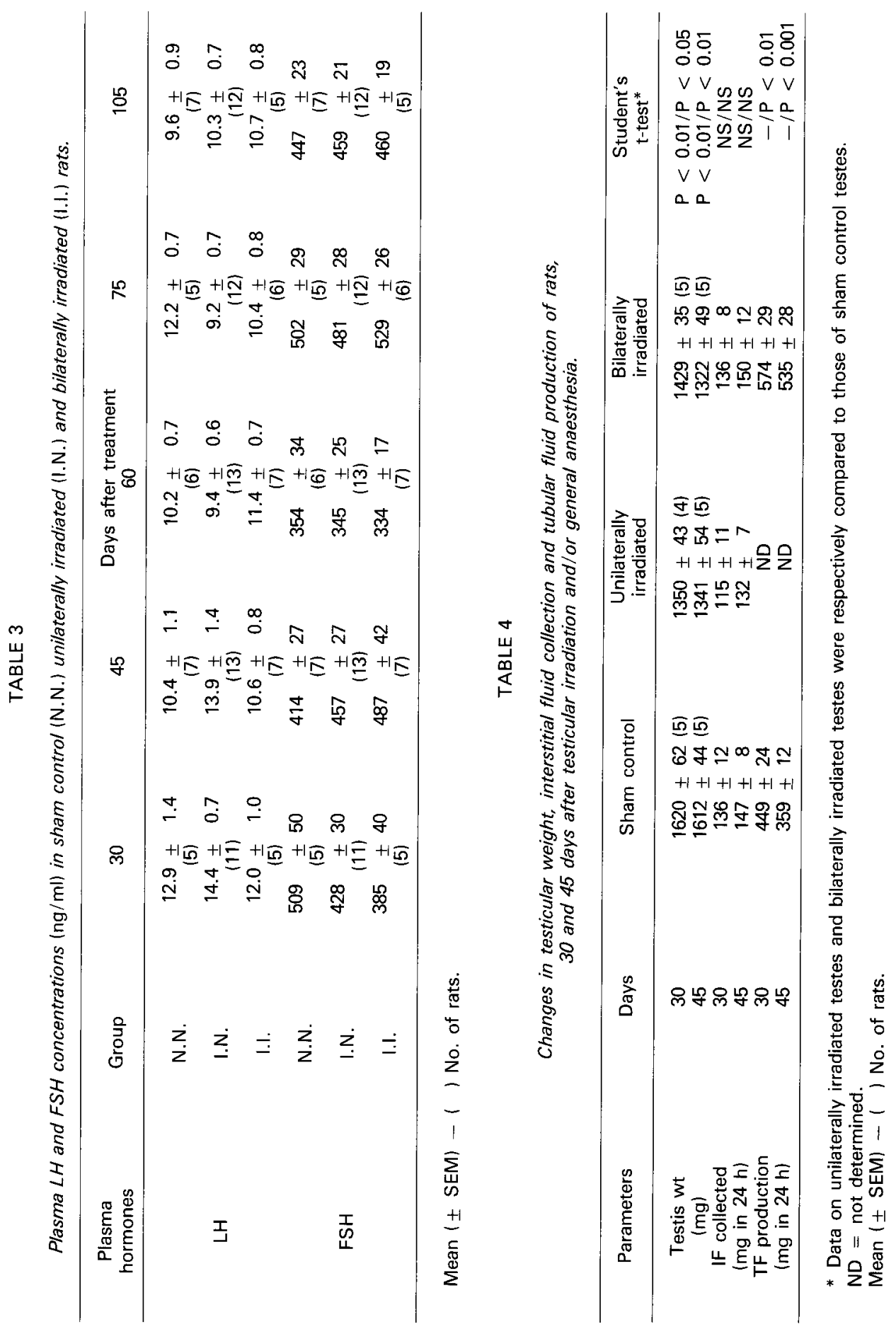
Water content and concentration of normal and irradiated testes. - Figure 2 combines data on water content and concentration in both types of normal testes (sham and protected) and in irradiated testes (unilateral and bilateral).

The water content of unligated irradiated testes was lower than that of normal testes. The difference was significant $(P<0.01) 30$ and 45 days after irradiation. Similar but more attenuated changes occurred in the water content of ligated irradiated testes compared to normal ligated testes.

The water concentration of normal testes (unligated and ligated) changed in similar way to their water content at all times after sham or protected exposure. As observed for TF production, the water concentration of irradiated testes (unligated and ligated) increased significantly 30 and $\mathbf{4 5}$ days after $\gamma$-ray exposure compared to normal testes and returned to normal values thereafter.

Plasma hormones. - There were no significant variations among any of the groups of rats at any of the times after $\gamma$-ray exposure as regards plasma $\mathrm{FSH}$, LH, PRL and testosterone concentrations. LH levels showed greater variation than FSH (table 3). Plasma testosterone concentrations were generally low $1<1 \mathrm{ng} / \mathrm{ml}\rangle$ in all groups and showed no consistent pattern, varying as much within a group as among groups. Plasma PRL concentrations also fluctuated widely without showing any significant variations.

\section{Experiment 2.}

Thirty and 45 days after $\gamma$-ray or sham exposure the amounts of IF collected over $24 \mathrm{~h}$ did not differ significantly between irradiated and control testes, although the production of the irradiated testes decreased slightly (table 4). As in experiment 1 , TF increased significantly $30(P<0.01)$ and $45(P<0.001)$ days after irradiation compared with the sham controls, whilst testicular weight decreased significantly (table 4).

\section{Discussion.}

Experimental conditions. $-\gamma$ or X-ray exposure induces a transient disruption of the germinal epithelium by killing type $A$ spermatogonia (Dym and Clermont, 1970 ; Erikson and Martin, 1973 ; Oakberg, 1975 ; Hopkinson et al., 1978 ; Huckins, 1978), and thus subsequent depletion of the germ cells. In adult rodents the minimal acute dose of $X$-rays required to induce temporary infertility is about 1 to $3 \mathrm{~Gy}$, depending on the species and the genetic strain (Oakberg, 1975 ; Setchell, 1978). The quality of the radiation is also important. $\gamma$-rays being more penetrating than $X$-rays, we used a total dose of 0.8 Gy of $\gamma$-rays after an unsuccessful preliminary experiment using $3 \mathrm{~Gy}$. While not affecting all the seminiferous tubules, this dose $(0.8 \mathrm{~Gy})$ was sufficient to cause a significant decrease in testicular weight 30 and 45 days later (fig. 1), reflecting a progressive but less complete effect on spermatogenesis than that obtained previously with an i.p. injection of busulfan (Laporte and Gillet, 1975). The increase in testicular weight from 60 to 105 days after irradiation (fig. 1) indicated that the tubules were 
repopulated by a division of the radio-resistant stem spermatogonia. The Sertoli cells of adult, but not immature, mammals are usually thought to be morphologically unaffected by radiation (Courot, 1963; Erickson and Blend, 1976). The same should be true of the Leydig cells since testosterone production is not affected by a moderate dose of radiation (Setchell, 1978), as confirmed by the lack of differences in the seminal vesicle weights of our rats. This may explain why plasma LH did not change significantly. In our experimental conditions, plasma FSH (table 2) and PRL did not increase significantly either. Similar results were observed for FSH by Delic et al. (1983). On the contrary, after more drastic treatments such as busulfan injection (Gomes et al., 1973), 5 to $6 \mathrm{~Gy}$ of $\gamma$-ray exposure (Wang et al., 1983), or heating to $43{ }^{\circ} \mathrm{C}$ (Jegou et al., 1984), a significant increase in serum $\mathrm{FSH}$ and, in some cases, of $\mathrm{LH}$, was observed.

Hemicastration under ether anaesthesia $24 \mathrm{~h}$ before sacrifice does not alter TF production by the remaining testis or its sensitivity to hCG (Laporte, 1979). Nevertheless, it is well known that ether inhalation decreases the level of plasma testosterone in rats during the first $24 \mathrm{~h}$ after it is given (Bardin and Peterson, 1967) ; this was true in the present work (basal levels : $\leq 1 \mathrm{ng} / \mathrm{ml}$ ).

When determining TF production in rats in which the two testes were not in the same morphological and physiological states (as after unilateral irradiation) we could not use the classical method of Smith (1962) as such. However, we adapted the method to our needs by determining the water content of each ligated testis before (calculated values) and after (true experimental values) ligation.

This method assumed that the dry weight of the unligated testes was not statistically different from that of the testes ligated for a period of $24 \mathrm{~h}$. This proved to be the case, not only for rats sacrificed 30 and 45 days after treatment (fig. 1), but also for all others killed later (data not shown). The validity of this improved method was supported by the similar TF production observed in the four groups of rats 105 days after treatment (table 2), when their testicular weights no longer differed significantly (fig. 1). Consequently, this method can be extended to animals submitted to other experimental designs inducing different testicular states in the same animals, as, for example, hemicastration, hemicryptorchidism and local unilateral drug or heat treatments.

Experimental results. - Thirty and 45 days after unilateral and bilateral testicular irradiation, we observed an increase in TF production (table 2) and water concentration (fig. 2), while spermatogenesis was partly and progressively disrupted. This increase occurred without any change in the IF collected (table 4) or in any of the plasma hormones studied (table 3). From these observations, the acute variations in TF seemed to be independent of any peripheral hormones. The testicular fluid is the sum of the intratubular (TF) and the extratubular (IF) fluids. The lack of variation in the IF collected demonstrates that the permeability of the testicular capillaries does not change (Setchell and Sharpe, 1981 ; Sharpe and Cooper, 1983) and that modifications in the testicular fluid are in fact changes in the tubular fluid, as previously shown in growing rats by Jegou et al. (1982).

At 60,75 and 105 days after treatment, tubular fluid production and the water concentration of irradiated gonads decreased to normal levels while 
spermatogenesis was resumed. This successive increase and decrease in tubular fluid production in irradiated rats did not occur in the protected testes of those which were unilaterally irradiated, except at day 30 when their TF secretion was greater than that in the normal testes of sham control rats (table 2). This could be due to slight, unintentional irradiation of the contralateral testis, as shown by its lower but not significantly different weight (fig. 1), or to random fluctuations among groups of rats. This inverse relationship between the activities of the germinal line (partly and transiently affected by $\gamma$-rays) and the Sertoli epithelium corroborates our previous results in busulfan-treated rats (Laporte and Gillet, 1975). Both observations lead us to suggest a local and inhibitory influence of the germ cells on the fluid secreted by the Sertoli cells in adult as well as in sexually maturing rats (Laporte and Gillet, 1984). Such an hypothesis has been proposed previously by Barack (1958) in mice. In rams during the cannulation period, the flow rate of the rete testis fluid tends to increase slightly while sperm concentration decreases severely (Dacheux et al., 1981).

Our results in rats do not agree with those of Jegou et al. (1984) who observed a decreased ABP and fluid secretion 14 and 26 days after heating the testes to $43^{\circ} \mathrm{C}$. It is possible that this method directly affected not only the postmeiotic germ cells, but also the Sertoli (Hagenäs et al., 1978) and Leydig (Risbridger et al., 1981) cells. In our moderate experimental conditions, germ cell influence on tubular fluid secretion could be due to several factors : (1) inhibin secretion might change; this change would not be sufficient to significantly increase plasma FSH level, but it could locally modulate the sensitivity of Sertoli cell FSH receptors, as suggested by Vijayalakshmi et al. (1980). Such inhibitors of FSH receptor binding have also been evidenced in follicular fluid (Sluss and Reichert, 1984); (2) inhibitory factors may be present in the germ cells. This opinion is supported by the observed reduction in Sertoli adenylylcyclase when a high concentration of germ cell cytosol is added to the culture medium (Welsch et al., 1984); (3) the Sertoli cell secretion of inhibin and/or the inhibition of some Sertoli enzymes by germ cell cytosol could be related to a more or less important phagocytosis of the residual bodies of late spermatids (LACY, 1967). This would explain why the more the spermatids were depleted (at 45 days post-irradiation), the more the tubular fluid was produced and vice-versa. Further investigations are needed to determine which types of germ cells or germ cell associations and factors are involved in these intercellular relationships controlling the active process of tubular secretion.

Reçu en juillet 1984.

Accepté en octobre 1984.

Acknowledgements. - This work was supported by grants from « Délégation Générale à la Recherche Scientifique et Technique " (DGRST-80-02). The rat FSH radio-immunoassay kit, rat antiserum, purified rat $L H S \times 1-1$, testosterone antiserum, rat $P R L$ antiserum and purified PRL-I.N.R.A. were generously provided by NIAMDD (Bethesda, Maryland) and Drs. M. Dubois, M. Jutisz, G. Pacaper and N. Martinat, respectively. We are grateful to Drs. M. Courot and B. Jegou for helpful comments on the manuscript and wish to thank $L$. Terriot for the illustrations and M. R. J. Kilgour for correcting the English. 
Résumé. Production du fluide testiculaire et concentration des hormones plasmatiques chez le rat adulte après irradiation gonadique par le cobalt 60.

Des rats Wistar adultes, soumis à une irradiation testiculaire par le cobalt $(0,8 \mathrm{~Gy})$, ont été répartis en 4 groupes (témoins, irradiés unilatéralement $(2$ lots) et irradiés bilatéralement). Des rats de chaque groupe furent sacrifiés $30,45,60,75$ et 105 jours après irradiation et/ou anesthésie générale. La production du fluide tubulaire, estimée par une variante personnelle de la méthode de Smith (1962), augmente significativement 30 et 45 jours après irradiation ( $P<0,001)$ dans les testicules irradiés uni- et bilatéralement, comparée à celle des 2 types de testicules témoins, non irradiés et protégés. Au contraire, le fluide interstitiel, recueilli selon la méthode de Sharpe (1977), ne diffère pas dans les testicules irradiés et témoins, alors que le poids des testicules irradiés diminue significativement. Du $60^{\circ}$ au $105^{\circ}$ jour après irradiation, le volume du fluide tubulaire sécrété s'abaisse progressivement aux valeurs des témoins tandis que le poids testiculaire augmente. Chez les rats irradiés, les concentrations des hormones dosées dans le plasma (FSH, LH, PRL et testostérone) ne présentent aucune différence significative avec celles des témoins. Ces résultats suggèrent en conséquence un contrôle local de la sécrétion du fluide sertolien par la lignée germinale.

\section{References}

BARACK B. M., 1968. Transport of spermatozoa from seminiferous tubules to epididymis in the mouse : a histological and quantitative study. J. Reprod. Fert., 16, 35-48.

BARDIN C. W., PETERSON R. E., 1967. Studies of androgen production by the rat : testosterone and androstenedione content of blood. Endocrinology, 80, 38-44.

COUROT M., 1963. Some results obtained in the irradiation with X-rays of testes of lambs, 279-286. In W. CARLSON, F. GASSNER. Effects of ionizing radiation on the reproductive system. Pergamon Press, New York.

DACHEUX J. L., PISSELET C., BLANC M. R., HOCHEREAU-de REVIERS M. T., COUROT M., 1981. Seasonal variations in rete testis fluid secretion and sperm production in different breeds of ram. J. Reprod. Fert., 61, 363-371.

DELIC J. I., HENDRY J. H., MORRIS I. D., SHALET S. M., 1983. Serum FSH, ABP and regeneration of the seminiferous epithelium after local testicular irradiation. 8th testis workshop. " Hormone action and testicular function ". NICHHD Bethesda, Ma.

DYM M., CLERMONT Y., 1970. Role of spermatogonia in the repair of the seminiferous epithelium following $X$-irradiation of the rat testis. Amer. J. Anat., 128, 265-282.

ERICKSON B. H., BLEND M. $J_{60}, 1976$. Response of the Sertoli cell and stem germ cell to Co $\gamma$-radiation (dose and dose rate) in testes of immature rats. Biol. Reprod., 14, 641-650.

ERICKSON B. H., MARTIN P. G., 1973. Influence of age on the response of rat stem spermatogonia to $\gamma$-radiation. Biol. Reprod., 8, 607-612.

FREE M. J., 1980. "Leaky » membranes in the male reproductive tract : a discussion of unusual molecular exchanges between different fluid compartments, 281-290. In A. STEINBERGER, E. STEINBERGER, Testicular development, structure and function, Raven Press, New York.

GOMES W. R., HALL R. W., JAIN S. K., BOOTS L. R., 1973. Serum gonadotropin and testosterone levels during loss and recovery of spermatogenesis in rats. Endocrinology, 93, 800-809.

HAGENAS L., RITZEN E. M., SVENSSON J., HANSSON V., PURVIS K., 1978. Temperature dependance of Sertoli cell function. Int. J. Androl., Suppl., 2, 449-456.

HOPKINSON C.N.R., DULISCH B., GAUSS G., HILSCHER W., HIRSCHHÄUSER C., 1978. The effect of local testicular irradiation on testicular histology and plasma hormone levels in the male rat. Acta. endocr., Copenh., 87, 413-423.

HUCKINS C., 1978. Behavior of stem cell spermatogonia in the adult rat irradiated testis. Biol. Reprod., 19, 747-760. 
JEGOU B., LE GAC F., de KRETSER D. M., 1982. Seminiferous tubule fluid and interstitial fiuid production. I. Effects of age and hormonal regulation in immature rats. Biol. Reprod., 27, 590-595.

JEGOU B., LAWS A. O., de KRETSER D. M., 1984. Changes in testicular function induced by short-term exposure of the rat testis to heat : further evidence for interaction of germ cells, Sertoli cells and Leydig cells. Int. J. Androl., 7, 244-257.

LACY D., 1967. The seminiferous tubules in mammals. Endeavour, 26, 101-108.

LAPORTE P., 1979. Evolution physiologique et facteurs de variations des acides sialiques dans I'unité testiculo-épididymaire et du fluide dans le testicule, chez le rat normal et aspermatogène. Th. Doct. Sci., Univ. Poitiers, $\mathrm{n}^{\circ} 290$.

LAPORTE P., GILLET J., 1975. Influence de la spermatogenèse sur la sécrétion du fluide testiculaire chez le rat adulte. C. R. Acad. Sci., Paris, 281, 1397-1400.

LAPORTE P., GILLET J., 1984. Changes with age in the testicular fluid secretion of normal and aspermatogenic rats. IRCS Med. Sci, 12, 54-55.

MARTINAT N., HALL E., RAVAULT J. P., DUBOIS M. P., 1979. Purification of rat prolactin : development of an homologous radioimmunological assay and comparison with the NIAMDD system. Annl. Biol. anim. Biochim. Biophys., 19, 1771-1788.

OAKBERG E. F. 1975. Effects of radiation on the testis. In A. D. JOHNSON, W. R. GOMES. Handbook of Physiology, Vol. 5, 233-243. Acad. Press, New York.

RISBRIDGER G. P., KERR J. B., de KRETSER D. M., 1981. Evaluation of Leydig cell function of gonadotrophin binding in unilateral and bilateral cryptorchidism : evidence for local control of Leydig cell function by the seminiferous tubule. Biol. Reprod., 24, 534-540.

RITZEN E. M., HANSSON V., FRENCH F. S., 1981. The Sertoli cell, 171-194. In H. BURGER, D. M. de KRETSER. The testis. Raven Press, New York.

SETCHELL B. P. 1969. Do Sertoli cells secrete the rete testis fluid ? J. Reprod. Fert., 19, 391-392.

SETCHELL B. P., 1978. Naturally occurring and induced dysfunctions of the testis, 359-342. In SETCHELL B. P., The mammalian testis. Eds Paul Eleck, London.

SETCHELL B. P., SHARPE R. M., 1981. Effect of injected hCG on capillary permeability, extracellular fluid volume and the flow of lymph and blood in the testes of rats. J. Endocr., 91, 245-254.

SHARPE R. M., 1977. Relationship between testosterone, fluid content and luteinizing hormone receptors in the rat testis. Biochem. Biophys. Res. Commun., 75, 711-717.

SHARPE R. M., COOPER I., 1983. Testicular interstitial fluid as a monitor for changes in the intratesticular environment in the rat. J. Reprod. Fert., 69, 125-135.

SLUSS P. M., REICHERT Jr L. E., 1984. Porcine follicular fluid contains several low molecular weight inhibitors of FSH binding to receptors. Biol. Reprod., 30, 1091-1104.

SMITH G., 1962. The effects of ligation of vasa efferentia and vasectomy on testicular function in the adult rat. J. Endocr., 23, 385-399.

VIGUIER-MARTINEZ M. C., 1976. Plasma LH response to LH-RH injection in immature intact, castrated and cyproterone-treated male rats. J. Reprod. Fert., 48, 195-197.

VIGUIER-MARTINEZ M. C., HOCHEREAU de REVIERS M. T., BARENTON B., PERREAU C., 1984. Effect of prenatal treatment with busulfan on the hypothalamo-pituitary axis, genital tract and testicular histology of prepubertal male rats. J. Reprod. Fert., 70, 67-73.

VIJAYALAKSHMI S., MOODBIDRI S. B., BANDIVDEKAR A. H., SHETH A. R., 1980. Modulation of FSH action by inhibin. Arch. Androl., 5, 231-235.

WAITES G. M. H., 1977. Fluid secretion. In A. D. JOHNSON, W. R. GOMES. The testis, Vol. 4, 91-123. Acad. Press, New York.

WAITES G. M. H., GLADWELL R. T., 1982. Physiological significance of fluid secretion in the testis and blood-testis barrier. Physiol. Rev., 62, 624-655.

WANG J., GALIL K. A. A., SETCHELL B. P., 1983. Changes in testicular blood flow and testosterone production during aspermatogenesis after irradiation. $J$. Endocr., 98, 35-46.

WELSCH M. J., TREISMAN G. J., IRELAND M. E., 1984. Germ cell activation of Sertoli cell adenylyl cyclase, p. 77. In 3rd European Workshop on molecular endocrinology of the testis. Lyon, France. 